\title{
Early stages of somatic embryogenesis in plumule explants of Philippine Makapuno hybrid VMAC5
}

\author{
Kenn Erika T. Juanillo ${ }^{1}$ and Tessie C. Nunez ${ }^{2 *}$
}

Early bearing, self-pollinating and medium-to-big-seeded Philippine makapuno hybrid VMAC5 is propagated through in vitro embryo culture. This yields one plantlet per embryo in at least six months. To evaluate the potential of mass producing planting materials in vitro, a protocol developed by the Philippine Coconut Authority was used to initiate somatic embryogenesis in whole and cut plumule explants from VMAC5 nuts. Calloid initiation was obtained 8 to 12 days from initial culture in semi-solid medium under dark incubation at $8 \%$ in cut and $5 \%$ in whole plumules. White translucent structures characteristic of embryogenic calloids formed on the cut plumules one month after initial culture. At 60 days old, distinct ear-shaped pre-embryogenic structures and white shiny globular pre-somatic embryos developed in whole explants. Hard, friable, and whitish to yellowish calloids with pre-embryogenic masses were also observed in cut plumule explants. At 90 days after the initial culture, more distinct pre-somatic and globular somatic embryos developed in both explants.

Keywords: Makapuno hybrid, in vitro culture, plumule explants, somatic embryogenesis, coconut

\section{INTRODUCTION}

Coconut (Cocos nucifera L.) is propagated sexually producing one seedling per nut in one and a half years from pollination. Propagation of rare genotypes, like the Philippine makapuno (VMAC) hybrids developed by the Visayas State University (VSU), is constrained by the limited number of nuts per palm. In Mexico, an efficient

'Department of Biotechnology and National Coconut Research Center-Visayas, Visayas State University, Baybay City, Leyte, Philippines

${ }^{2}$ Formerly with the National Coconut Research Center-Visayas, Visayas State University, Baybay City, Leyte, Philippines

*Corresponding Author. Address: Formerly with the National Coconut Research Center-Visayas, Visayas State University, Baybay City, Leyte, Philippines; Email: tessie.nunez@vsu.edu.ph 
micropropagation system was developed which was reported to yield 98,000 somatic embryos per plumule via somatic embryogenesis (Oropesa et al 2016, Saenz-Carbonell 2004). Although the resulting plantlets are not genetically identical with heterozygous mother palms since plumules are from products of pollination, the protocol could be very useful in mass propagation of palms which are desired for at least one very important trait such as the makapuno.

The Philippine Coconut Authority (PCA) developed a similar protocol with an output of more than 280 plantlets from a single plumule in three years (pers com, Ubaldo et al 2016). The PCA's protocol was tested for normal coconuts but no study was reported yet of its suitability for rare genotypes like the makapuno. This study evaluated the early responses to the PCA's somatic embryogenesis technology of the medium-to-big-seeded makapuno hybrid VMAC5, produced from a cross between Tacunan Dwarf and UPLB Tall Makapuno. Variations in in vitro responses of plumule explants have been reported due to several factors such as basal medium (Zegzouti 2001), culture conditions, genotypes (Kim et al 2003) and the explant source (Sherma and Rajam 1995).

VMAC5 is planted only in the VSU experimental field and very few palms were planted in other places due to limited planting materials. Due to its thick (about $14 \mathrm{~mm}$ ) and firm (7.13-12.17kg per $\mathrm{cm}^{2}$ ) meat (Leorna 2017), it is very suitable as a raw material for sweetened makapuno balls and strips. Increasing the current number of field-planted VMAC5 by producing more planting materials will enhance the economic potential of the aforementioned processed makapuno products.

\section{MATERIALS AND METHODS}

\section{Media Preparation}

Y3 (Eeuwens 1976) medium supplemented with different combinations of 2, 4 dichlorophenoxyacetic acid (2, 4-D) and 6-benzylaminopurine (BAP) was prepared following the IPR-protected formulations developed by PCA (pers com, Cueto 2016). The concentrations of plant growth regulators (PGRs) were varied to suit the requirements for calloid initiation and somatic embryo development.

\section{Sources and Preparation of Plumule Explants}

Zygotic embryos were collected from newly harvested 10-11 month old VMAC5 makapuno nuts from the National Coconut Research Center-Visayas (NCRC-V), Visayas State University (VSU) following the procedure developed by Rillo (1995). Plumules were aseptically excised from the embryos and used as explants (Cueto 2016, Personal Communication).

\section{In Vitro Culture}

Plumule explants were inoculated singly, as whole or cut into six to seven small pieces as treatments, onto the callus induction medium. Ten plumules were used per treatment in a Completely Randomized Design with four replicates. Cultures were incubated in dark conditions for one month at $28 \pm 1^{\circ} \mathrm{C}$. The first subculture was done 30 days after initial culture (DAI) in a medium with lower percentages of PGRs 
and incubated for another 30 days. The second subculture was done after 30 days in the same medium formulation. Calloid development was monitored for 90 days from initial culture. The diameter of each calloid was measured under a stereomicroscope with a built-in micrometer. Data were analyzed using t-test.

\section{RESULTS AND DISCUSSION}

\section{Calloid Initiation}

VMAC5 plumule explants formed calloids similar to normal coconuts (Hornung 1995, Saenz et al 2018). Calloid initiation started on the $8^{\text {th }}$ to the $12^{\text {th }}$ DAI. A similar culture duration of 1-2 weeks from inoculation to calloid development was reported in immature embryos from normal coconuts (Karunaratne and Periyapperuma 1990). The average duration from inoculation to calloid initiation was 9 days in whole and 10 days in cut explants (Figure 1 A). Delay in calloid initiation in cut explants could be due to browning as a result of oxidation of phenolic compounds in the wounded surfaces of the explants, which can inhibit normal cell growth or cause cell death in severe cases (Ahmad et al 2013). Calloid initiation in both explants was low at $5 \%$ in whole and $8 \%$ in cut plumules at $12 \mathrm{DAl}$ (Figure 1B).

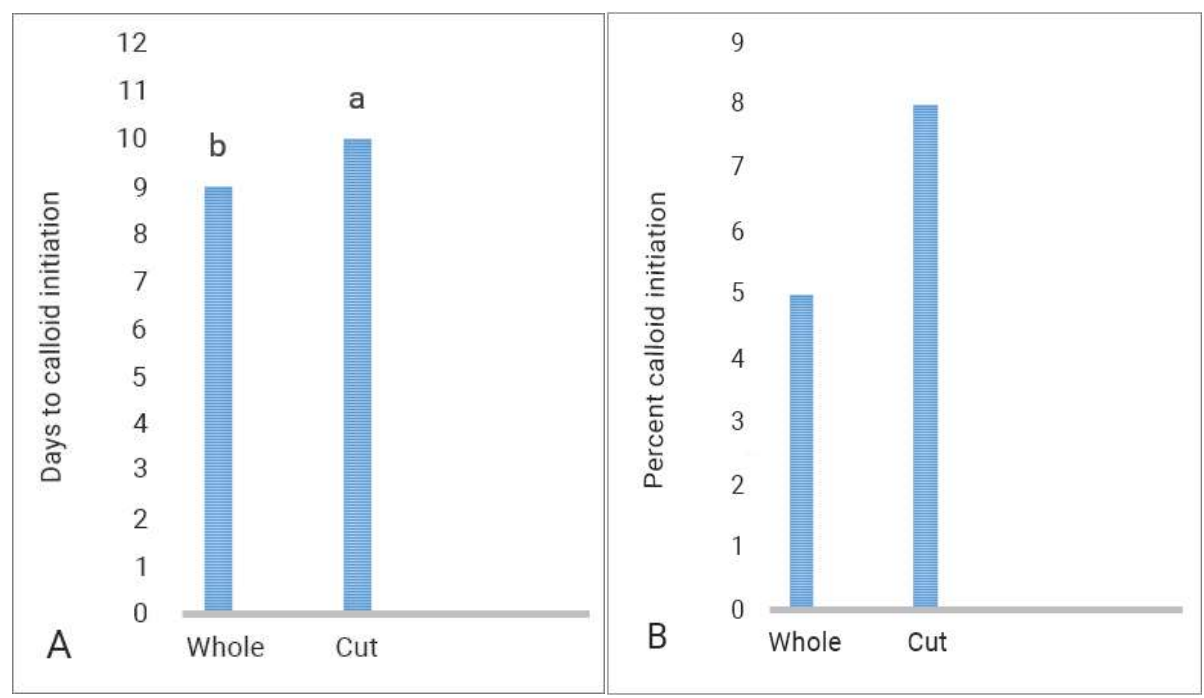

Figure 1. Calloid initiation in whole and cut plumule explants of VMAC5

\section{Growth and Development of Calloids}

The initial calloids at 8 to $12 \mathrm{DAl}$ had an average diameter of $0.2 \mathrm{~cm}$ in whole explants. In cut explants, the total diameter of calloids from all pieces of a plumule averaged $0.4 \mathrm{~cm}$ (Table 1 ). Calloids developed on the surface of the explants. These were relatively bigger in cut than in whole explants. They were white and bulging in whole explants (Figure $2 \mathrm{~A}$ ) but yellowish and compact in cut plumules (Figure 2B). 
Table 1. Average diameter $(\mathrm{cm})$ of calloids in whole and cut plumule explants from initiation to 90 days in culture

\begin{tabular}{ccc}
\hline Days after Inoculation & Whole Plumule & Cut Plumule \\
\hline $8-12$ & 0.2 & 0.4 \\
30 & 0.4 & 0.7 \\
60 & 0.6 & 0.9 \\
90 & 0.9 & 1.0 \\
\hline
\end{tabular}

At $30 \mathrm{DAl}$, the calloids' average diameter was $0.4 \mathrm{~cm}$ in whole and $0.7 \mathrm{~cm}$ in cut explants. Calloids in whole explants were compact with white to beige or cream color (Figure 3C). On the other hand, development of distinct white translucent structures characteristic of embryogenic calloids was observed on the surface of some cut plumules (Figure 3D). Pieces without calloids turned yellow or brownish possibly due to the production of phenols as a consequence of cutting. Browning results from oxidation of the phenolic compounds.

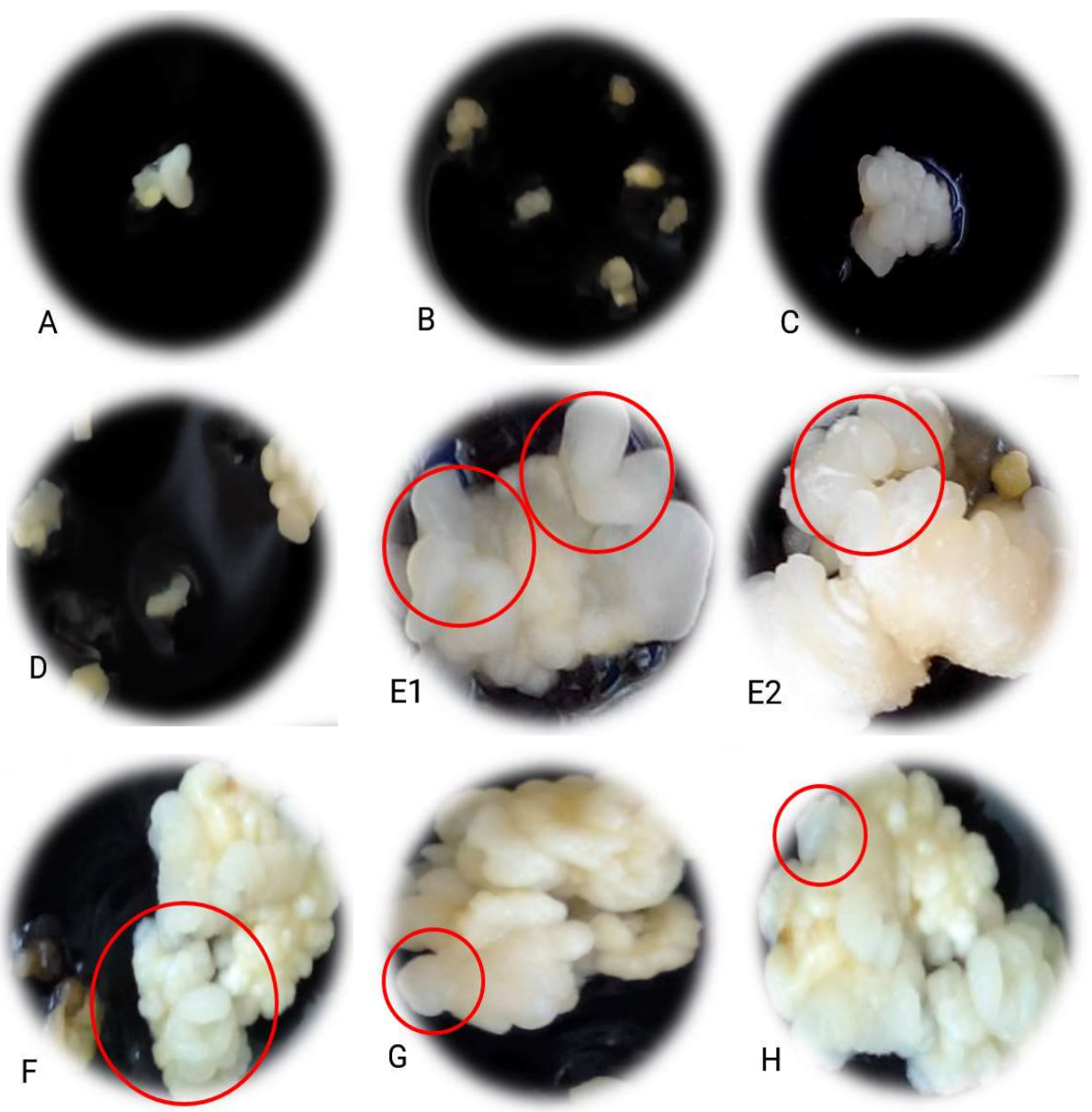

Figure 2. Early stages of somatic embryogenesis in in vitro-cultured_VMAC5 plumule explants: calloid initiation at 8-12 DAl in whole (A) and cut (B), growing calloids at $30 \mathrm{DAl}$ in whole (C) and cut (D), earshaped pre-embryogenic structures (E1) and globular pre-somatic embryos at $60 \mathrm{DAI}(\mathrm{E} 2)$ in whole, embryogenic calloids at $60 \mathrm{DAl}$ in cut (F), and globular somatic embryos at $90 \mathrm{DAl}$ in whole (G) and cut (H) 
At $60 \mathrm{DAl}$, calloids in whole and cut plumule explants grew to $0.6 \mathrm{~cm}$ and $0.9 \mathrm{~cm}$ average diameters, respectively. Distinct ear-shaped pre-embryogenic structures were observed in whole explants (Figure 2E1). This development was similar to the report of Oropeza et al (2016) on somatic embryogenesis in normal coconuts. White and shiny globular structures also started to form (Figure 2E2). These were considered as pre-somatic embryos. Hard, friable whitish to yellowish calloids with pre-embryogenic masses developed in some cut plumule explants (Figure 2F), while others did not show further development.

During the second subculture, at 60-90 DAl, the explants produced profuse calloids with an average diameter of $0.9 \mathrm{~cm}$ in whole and $1.0 \mathrm{~cm}$ in cut plumule explants. They were beige to yellowish white in color. Some calloids were compact, some were bulging, while others broke apart into small globular structures. More distinct individualized structures considered as pre-somatic embryos developed from the embryogenic calloids in whole plumule explants. Initial formation of white and shiny globular embryos was observed (Figure 2G). The calloids from cut plumule explants likewise produced a few pre-somatic embryos which were whitish and transluscent. Globular somatic embryos also formed in one culture (Figure $2 \mathrm{H}$ ).

\section{CONCLUSIONS}

This study showed that VMAC5 plumules from 10-11 month-old nuts respond positively to the somatic embryogenesis technology developed by PCA and can be used as explants to mass produce this makapuno hybrid. Improvement in handling the plumules or in the medium formulation is necessary to increase the percentage of calloid initiation. Apparently, whole plumules produce better quality calloids with more distinct pre-somatic and globular embryos than cut explants during the early stages of development. Nevertheless, globular somatic embryos can be obtained from responsive calloids of both explants as early as 90 days from initial culture.

\section{ACKNOWLEDGMENT}

The authors are profoundly thankful to Dr. Maria Juliet C. Ceniza, Director of the National Coconut Research Center-Visayas, Visayas State University, and the staff of the VSU Makapuno Laboratory for allowing the use of the laboratory facilities during the conduct of this study.

\section{REFERENCES}

Ahmad I, Hussain T, Ashraf I, Nafees M, Maryam, Rafay M \& Iqbal M. 2013. Lethal effects of secondary metabolites on plant tissue culture. American-Eurasian Journal of Agricultural and Environmental Sciences 13(4):539-547

Areza-Ubaldo MB, Rillo EP \& Cueto CA. 2016. Application of the improved embryo culture protocol for commercial production of makapuno seedlings. Philippine Journal of Science 132(1):1-11

Eeuwens CJ. 1976. Mineral requirements for growth and callus initiation of tissue explants excised from mature coconut palms (Cocos nucifera L.) cultured in vitro. Physiologia Plantarum 36(1):23-28 
Hornung R. 1995. Micropropagation of Cocos nucifera L. from plumular tissues excised from mature zygotic embryos. Plantations, Recherche, Developpement 2(2):38-41

Karunaratne S and Periyapperuma K. 1990. Culture of immature embryos of coconut, Cocos nucifera L: Callus proliferation and somatic embryogenesis. $\operatorname{cocos} 8: 13-22$

Kim SW, In DS, Kim TJ \& Liu JR. 2003. High frequency somatic embryogenesis and plant regeneration in petiole and leaf explant cultures and petiole-derived embryogenic cell suspension cultures of Hylomecon vermalis. Plant Cell Tissue and Organ Culture 74:163-167

Leorna MTA. 2017. Physicochemical and biochemical profiling of VMAC5 for the development and process optimization of dehydrated "Makapuno" (Cocos nucifera L. 'makapuno'). In Annual Report 2017. National Coconut Research Center-Visayas, Visayas State University, Baybay City, Leyte

Oropesa C, Saenz L, Chan JL, Sandoval G, Perez-Nuñez T, Narvaez M, Rodriguez G \& Borroto C. 2016. Coconut micropropagation in Mexico using plumule and floral explants. Coconut Research and Development Journal (CORD) 32(2):21-26

Rillo EP. 1995. PCA's embryo culture technique in the mass production of makapuno coconuts.http://www.bioversityinternational.org/fileadmin/biover sity /publication/Web_version/363/ch2.htm

Sáenz-Carbonell L, Montero-Córtes M, Pérez-Nuñez T, Azpeitia-Morales A, AndradeTorres A, Córdova-Lara I, Chan-Rodríguez JL \& Oropeza-Salín C. 2013. Coconut (Cocos nucifera L.) somatic embryogenegis and related gene expression. In Aslam J, Srivastava PS \& Sharma MP (eds) Somatic Embryogenesis and Gene Expression (pp172-187). Narosa Publishing House, New Delhi

Sáenz L, Chan JL, Narvaez M \& Oropeza C. 2018. Protocol for the micropropagation of coconut from plumule explants. Methods in Molecular Biology 1815:161-170

Sherma P and Rajam MV. 1995. Genotype, explant and position effects on organogenesis and embryogenesis in eggplant (Solanum melongena L.). Journal of Experimental Botany 46(1):135-141

Zegzouti R, Arnold MF \& Favre JM. 2001. Histological investigation of the multiplication steps in secondary somatic embryogenesis of Quercus robur $\mathrm{L}$. Annals of Forest Science 58(6):681-690 